\title{
Poesia, arte e sensibilidade: contribuiçóes de um projeto de extensão para a formação de estudantes de terapia ocupacional ${ }^{1}$
}

\section{Poetry, art and sensitivity: contributions of an extension project for training occupational therapy students}

\author{
Vanessa Carolina Santos Francelino ${ }^{a}$ (D), Marília Meyer Bregalda ${ }^{a}$ (D)

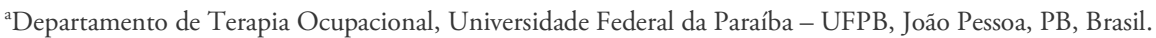

Como citar: Francelino, V. C. S., \& Bregalda, M. M. (2020). Poesia, arte e sensibilidade: contribuiçóes de um projeto de extensão para a formação de estudantes de terapia ocupacional. Cadernos Brasileiros de Terapia Ocupacional. 28(1), 50-73. https://doi.org/10.4322/2526-8910.ctoAO1820

\begin{abstract}
$\underline{\text { Resumo }}$
Objetivo: Este estudo visa apresentar as contribuições de um projeto intitulado Extensão Universitária em Poesia Ocupacional para a formação de estudantes de um curso de terapia ocupacional. O projeto se dedicava à formação para a atenção humanizada e sensível, com uso da arte e da poesia. Método: Trata-se de uma pesquisa qualitativa, em que se realizou análise documental dos materiais produzidos durante a vigência do projeto e aplicou-se um questionário semiestruturado com quinze discentes e ex-discentes do curso que compuseram suas equipes de execução. Os relatos provenientes dessas respostas passaram por análise de conteúdo e foram sistematizados em cinco categorias: motivaçóes para ingresso no projeto; princípios estruturantes e metodologias de funcionamento; contribuiçôes das atividades ofertadas; contribuições para a formação e atuação profissional; e avaliação do projeto. Resultados: A análise documental possibilitou sistematizar e descrever as atividades desenvolvidas pelo projeto, referidas principalmente a varais poéticos e rodas de conversa. A análise das respostas ao questionário identificou que o projeto acolhia e empoderava os estudantes para protagonizar sua formaçáo e promovia novas formas de aprender e ensinar e de produzir cuidado em terapia ocupacional, com base no uso da poesia e da arte, da horizontalidade das relaçôes, do uso de tecnologias leves e da problematização do cotidiano acadêmico e de questóes sociais. Conclusáo: $\mathrm{O}$ projeto contribuiu para que os estudantes se colocassem de forma potente, criadora, fossem capazes de se
\end{abstract}

\footnotetext{
${ }^{1}$ A pesquisa é resultante de um Trabalho de Conclusão de Curso de Terapia Ocupacional e não contou com nenhuma fonte de financiamento institucional. A pesquisa envolveu seres humanos e os procedimentos éticos vigentes foram cumpridos, com aprovação pelo Comitê de Ética e Pesquisa, com CAAE de no 91181618.0.0000.5188 e parecer de nº 2.777.805.
} 
reconhecer como agentes de transformação social, aprimorassem sua sensibilidade e qualificassem suas práticas nos espaços de formação e atuação profissional.

Palavras-chave: Formação Profissional, Extensão Comunitária, Humanização da Assistência, Tecnologia Leve, Terapia Ocupacional, Poesia.

\section{$\underline{\text { Abstract }}$}

Objective: This study aims to present the contributions of a project entitled University Extension Project in Occupational Poetry for the education of students of an Occupational Therapy course. The project was dedicated to training for humanized and sensitive attention, using art and poetry. Method: This was a qualitative research, in which documentary analysis of the materials produced during the project was carried out and a semi-structured questionnaire was applied to fifteen students and former students of the course that composed their execution teams. The reports from these answers went through a content analysis and were systematized into five categories: motivations for joining the project; structuring principles and methodologies of operation; contributions of the activities offered; contributions to training and professional performance; and project evaluation. Results: The documentary analysis enabled to systematize and describe the activities developed by the project, mainly referring to poetic clotheslines and conversation wheels. The analysis of the answers to the questionnaire identified that the project welcomed and empowers students to carry out their training and promoted new ways of learning and teaching and of producing care in Occupational Therapy, from the use of poetry and art, the horizontality of relationships, the use of soft technologies and the problematization of everyday academic and social issues. Conclusion: The project contributed to the students putting themselves in a powerful, creative way, and able to recognize themselves as agents of social transformation, to improve their sensitivity and to qualify their practices in spaces of professional formation and performance.

Keywords: Professional Training, Community-Institutional Relations, Humanization of Assistance, Soft Technologies, Occupational Therapy, Poetry.

\section{Introduçăo}

O presente estudo tem como objetivo apresentar as contribuiçóes do projeto intitulado Extensão Universitária em Poesia Ocupacional ${ }^{2}$, desenvolvido em um curso de terapia ocupacional, para a formação de estudantes que fizeram parte de sua equipe de execução. O projeto de extensão transitava entre as áreas de Saúde, Cultura, Educação e Social, visto se dedicar à formação para o cuidado em saúde e nos demais campos, com base na sensibilização do olhar possibilitada pela poesia e demais formas de manifestação de arte e cultura. Teve duração de dois anos, de dezembro de 2014 a dezembro de 2016, e sua equipe de execução era composta por docentes e estudantes do curso de terapia ocupacional e uma estudante do curso de Direito da mesma

${ }^{2} \mathrm{O}$ nome Poesia Ocupacional teve a intenção de ressaltar o uso da poesia nas açóes do projeto de extensão e deveu-se também à sonoridade próxima à do nome da profissão, Terapia Ocupacional. 
Instituição de Ensino Superior. Foram desenvolvidos varais poéticos e rodas de discussão sobre temáticas variadas, realizados principalmente em espaços da universidade, com participação de pessoas da comunidade acadêmica e não acadêmica.

Mecca \& Castro (2009) apontam que a arte possibilita aos sujeitos o reconhecimento de si e a expressão de seus sentimentos de forma singular. Com base em vivências entremeadas pelas artes de forma geral, e pela poesia, em específico, o projeto de extensão buscava oportunizar o exercício de uma compreensão sensível de si e do outro, que pudesse repercutir na produção de práticas profissionais mais sensíveis e humanizadas. Para Antônio (2013), a poesia transforma as relaçóes de ensino e aprendizagem, ao permitir uma comunicação mais próxima com o outro que, para além da transmissão de informaçóes, produza sentidos, imagens e emoções, eduque a sensibilidade e promova deslocamentos no sentido do desenvolvimento de práticas pedagógicas mais humanizadas.

A preparação de estudantes dos cursos da área da saúde para uma prática profissional humanizada e para lidar com as diferentes situaçóes e problemáticas dos serviços e do público atendido tem se constituído como um desafio para as instituiçóes de ensino superior. A formação desses profissionais deve superar o modelo biomédico centrado na doença, na figura do médico e no âmbito individual e curativo, e contemplar o desenvolvimento de abordagens e práticas críticas, criativas e sensíveis, baseadas em tecnologias leves, centradas nas relaçóes e que promovam o cuidado com o outro por meio da escuta, do acolhimento e do vínculo. Deve, também, possibilitar o protagonismo dos indivíduos e coletivos na produçáo de seu cuidado e na transformaçáo da realidade, tomando como base seus contextos e modos de vida (Merhy, 2005; Brasil, 2010; Constantinidis \& Cunha, 2013; Villardi et al., 2015).

A formação profissional para o cuidado humanizado pressupóe a produção pedagógica de espaços nos quais os estudantes possam vivenciar, praticar e sentir esse cuidado consigo e com o outro. A educação deve ser recriada de maneira a contemplar a reeducação dos afetos e a despertar o interesse pelo desenvolvimento da sensibilidade. Os ensinamentos teóricos não são suficientes e o cuidar precisa ser sentido, pois é mais que um ato, é uma atitude entrelaçada de responsabilidade e envolvimento afetivo entre pessoas (Coelho \& Fonseca, 2005; Antônio, 2013).

Casate \& Corrêa (2012) apontam que a atuação dos docentes universitários deve se pautar em açóes educativas que conjuguem os saberes científicos e os saberes humanísticos, para permitir ao estudante liberdade no processo de pensar, refletir e recriar. Desse pressuposto se basearam as ações desenvolvidas pelo projeto de extensão, no sentido da criticidade e das atitudes humanizadas que os estudantes de terapia ocupacional deveriam desenvolver nos encontros com as pessoas que atendem.

Vislumbrou-se a extensão universitária como forma apropriada de produzir experiências de protagonismo estudantil na formação humanizada em terapia ocupacional, o envolvimento entre professores e estudantes de forma dialógica e, ainda, a elaboração da práxis dos estudantes por meio da integraçâo com o que é aprendido nas atividades de ensino e pesquisa. A extensão oportuniza também a construção de uma formação crítica e reflexiva em ações contínuas, de caráter educativo, social e cultural, imprescindível àqueles que, como os terapeutas ocupacionais, dispóem-se a desenvolver açóes profissionais que valorizem a 
singularidade, os contextos e os modos de vida das pessoas atendidas pela profissão (Mendonça \& Silva, 2002; Jezine, 2004).

Assim, este artigo visa a apresentar os resultados da pesquisa sobre o projeto Extensão Universitária em Poesia Ocupacional, que teve como objetivos descrever e sistematizar as açóes nele desenvolvidas; identificar e compreender suas contribuiçóes para a formação profissional humanizada em terapia ocupacional; identificar suas contribuiçóes para as pessoas que participaram das atividades ofertadas - público-alvo; compreender os princípios, estratégias e metodologias utilizados no projeto; e levantar seus aspectos positivos e negativos.

\section{Método}

A pesquisa realizada é de natureza qualitativa e se caracteriza como um estudo descritivo e interpretativo dos pontos de vista e percepçóes de discentes e ex-discentes acerca das contribuiçóes do projeto Extensão Universitária em Poesia Ocupacional para sua formação. A abordagem qualitativa foi a mais apropriada ao estudo, pois valoriza os significados das experiências vivenciadas pelos sujeitos no mundo social (Pope \& Mays, 2009), e permitiu primar pela ótica dos participantes da pesquisa, considerando suas vivências e seus saberes adquiridos ao longo da extensão.

Foram convidados a colaborar com a pesquisa discentes e ex-discentes do curso de terapia ocupacional em que se desenvolveu o projeto, tendo sido incluídos aqueles que fizeram parte das suas equipes de execução. Foram excluídos discentes e ex-discentes que não fizeram parte dessas equipes, ou que delas participaram, mas abandonaram o curso e/ou eram de outros cursos que não o de terapia ocupacional.

Com base nas listas de frequência elaboradas durante a vigência do projeto, identificaram-se os 24 participantes de suas equipes de execuçâo. Após exclusão dos quatro que não se encaixavam nos critérios do estudo, e excetuando-se também a proponente da pesquisa, os contatos para convite à participação e envio do instrumento de coleta de dados se deram por correspondência eletrônica (e-mail), rede de comunicaçáo social e telefone, e obteve-se o retorno de 15 dos 20 contatados. A coleta ocorreu durante o mês de agosto de 2018.

O projeto de pesquisa foi aprovado pelo Comitê de Ética em Pesquisa do Centro de Ciências da Saúde da universidade, e fundamentado conforme as diretrizes da Resolução 466/2012 do Conselho Nacional de Saúde (Brasil, 2012). A participação na pesquisa foi antecipadamente apresentada aos participantes e consentida por meio do Termo de Consentimento Livre e Esclarecido (TCLE), assegurando-lhes o sigilo das informaçóes por eles concedidas e o direito de se retirar da pesquisa a qualquer momento, sem que isto lhes acarretasse dano. Esclareceu-se também aos participantes que apenas os dados relativos aos resultados da pesquisa poderiam ser publicados em revistas científicas e eventos.

A primeira etapa da pesquisa consistiu na análise documental dos materiais produzidos durante a extensão: projetos submetidos a editais de extensão, relatórios, atas de reuniōes, publicaçóes resultantes da participação em eventos e materiais como vídeos, fotografias e páginas nas redes de comunicação social. Esses documentos foram analisados com base nas seguintes etapas: organização das informaçóes, categorização e elaboração de sínteses. A análise documental, que se propóe a produzir ou reelaborar 
conhecimentos e criar novas formas de compreender os fenômenos, contribuiu para a compreensão do projeto, em conjunto com os resultados obtidos com a aplicação de um questionário, e possibilitou sistematizar conhecimentos produzidos pelas suas proposições e ações, referentes à construção de uma formação profissional humanizada em terapia ocupacional (Pimentel, 2001; Sá-Silva et al., 2009).

Para a obtenção dos demais dados da pesquisa, foi realizada a segunda etapa, que consistiu na aplicação, com os membros das equipes de execução selecionados, do questionário semiestruturado elaborado pela proponente da pesquisa e disponibilizado online, com o recurso do Google Docs, composto por oito perguntas abertas sobre as seguintes temáticas: motivaçóes para ingresso no projeto; impressóes pessoais acerca das atividades e intervenções desenvolvidas; contribuições do projeto para a formação e atuação profissional; percepçóes sobre as contribuições das atividades propostas para as pessoas que participavam das açóes ofertadas pelo projeto; consideraçóes sobre a integração da arte e da poesia nas atividades; expectativas iniciais acerca do projeto e seus aspectos positivos e negativos.

A análise de conteúdo dos relatos provenientes das respostas do questionário compreendeu a leitura e a sistematização desse material em categorias temáticas, norteadas pelos objetivos da pesquisa, para posterior tratamento dos dados e diálogo com a literatura sobre as temáticas abordadas (Gibbs, 2009). As categorias de análise identificadas foram: motivaçóes para ingresso no projeto; princípios estruturantes e metodologias de funcionamento; percepções sobre as contribuições das atividades ofertadas; contribuições para a formação e atuação profissional; e avaliação do projeto.

\section{Resultados e Discussão}

Primeiramente, será realizada a descrição do projeto Extensão Universitária em Poesia Ocupacional, com base na análise dos documentos produzidos durante sua vigência e das respostas ao questionário referidas às atividades desenvolvidas pelo projeto. Em seguida, serão apresentados os principais resultados provenientes das demais respostas ao instrumento, subdivididos de acordo com as categorias de análise supracitadas.

Os relatos dos participantes serão identificados pela letra "P”, seguida dos números de 1 a 15 . Dos 15 colaboradores da pesquisa, cinco são do gênero masculino e 10 do gênero feminino. A média de permanência no projeto de extensão foi de um ano e dois meses, tendo três estudantes participado durante os dois anos de sua vigência. Quanto à modalidade de inserção, 14 participaram como voluntários e uma como bolsista. Quatro dos 15 participantes ainda estão na graduação e onze já se formaram.

\subsection{Descrição da extensão universitária em poesia ocupacional}

As equipes de execução, compostas por docentes e estudantes do curso de terapia ocupacional e por uma estudante do curso de Direito da instituição, reuniam-se semanalmente para planejar e avaliar as atividades propostas, constituídas principalmente de varais poéticos e de rodas de discussão sobre temáticas demandadas pelo contexto acadêmico (Figuras 1 e 2). 


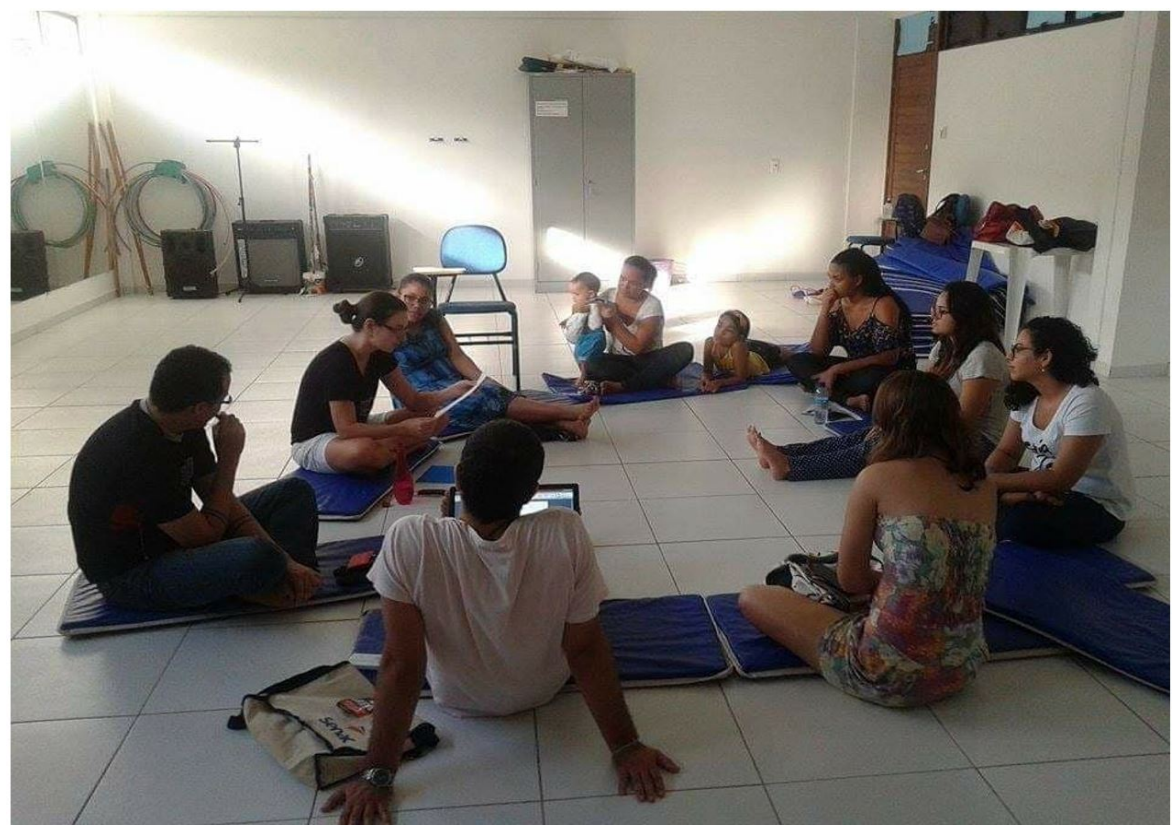

Figura 1. Reunião de planejamento, avaliação e estudos.

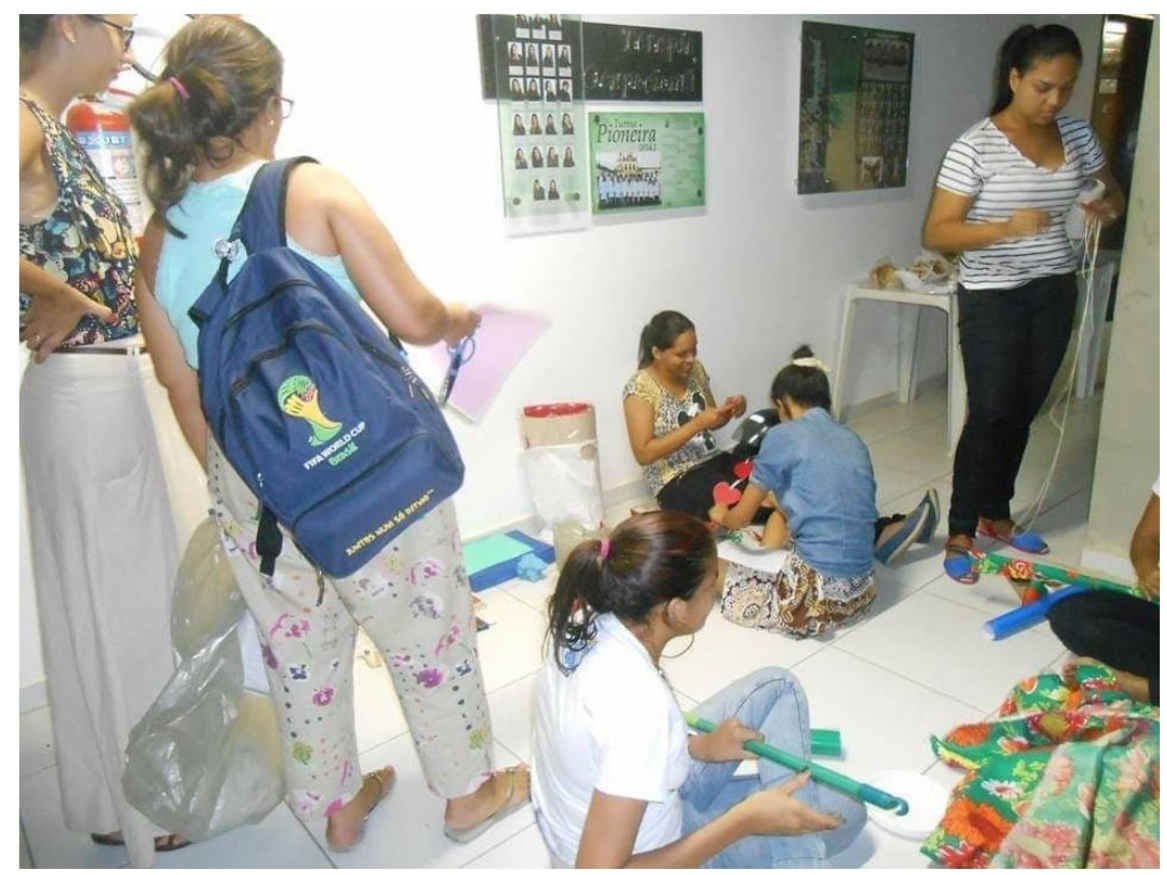

Figura 2. Preparação das açóes.

O projeto de extensão se propunha a problematizar a formação em saúde, com reflexôes sobre as formas de atuação dos futuros profissionais de terapia ocupacional que têm sido construídas na academia e discussóes sobre a importância do desenvolvimento de habilidades para utilização de tecnologias leves de cuidado. 
Os eventos promovidos ocorriam em espaços da universidade - área externa do Departamento de Terapia Ocupacional, Centro de Vivência, Praça da Alegria do Centro de Ciências Humanas, Letras e Artes, tendo somente uma vez ocorrido externamente a ela, no Espaço Cultural do município. As atividades ofertadas nesses eventos eram de participação livre e direcionadas a toda a comunidade acadêmica (estudantes, técnicos e docentes) e à comunidade externa à universidade. Eram valorizadas variadas possibilidades de expressão: relatos, músicas, poemas, vídeos, gestos, acolhendo o fazer de cada participante, problematizando a formaçáo por vezes engessada vivenciada na academia e propondo novas formas de desenvolvê-la.

As atividades do projeto tiveram início em dezembro de 2014 por meio do Fluxo Contínuo de Extensão (FLUEX), sob coordenação de uma docente do curso de terapia ocupacional. No ano de 2015, foi submetido ao Programa de Bolsas de Extensão (PROBEX) e, após aprovação nesse programa, passou a contar também com três docentes colaboradores do mesmo curso. A seleção de discentes foi ampliada a todos os cursos do Centro de Ciências da Saúde e do Centro de Ciências Médicas, mas todos os inscritos foram do curso de terapia ocupacional, tendo sido selecionados treze estudantes.

Algumas das ações desenvolvidas pela equipe de execução no ano de 2015 foram chamadas de "Varais Poéticos", encontros em que se utilizavam músicas, poemas, vídeos e imagens que pudessem disparar o diálogo entre os participantes presentes nos encontros. O primeiro varal, intitulado "Lave os seus sentimentos e venha estendê-los conosco!", abordou a expressão da poesia no cotidiano e contou com a declamação de poesias, autorais ou náo, que foram penduradas em varais para apreciação e discussão coletivas e cujos temas dialogaram por meio do acolhimento, escuta, respeito e troca de afetos entre os participantes (Figura 3).

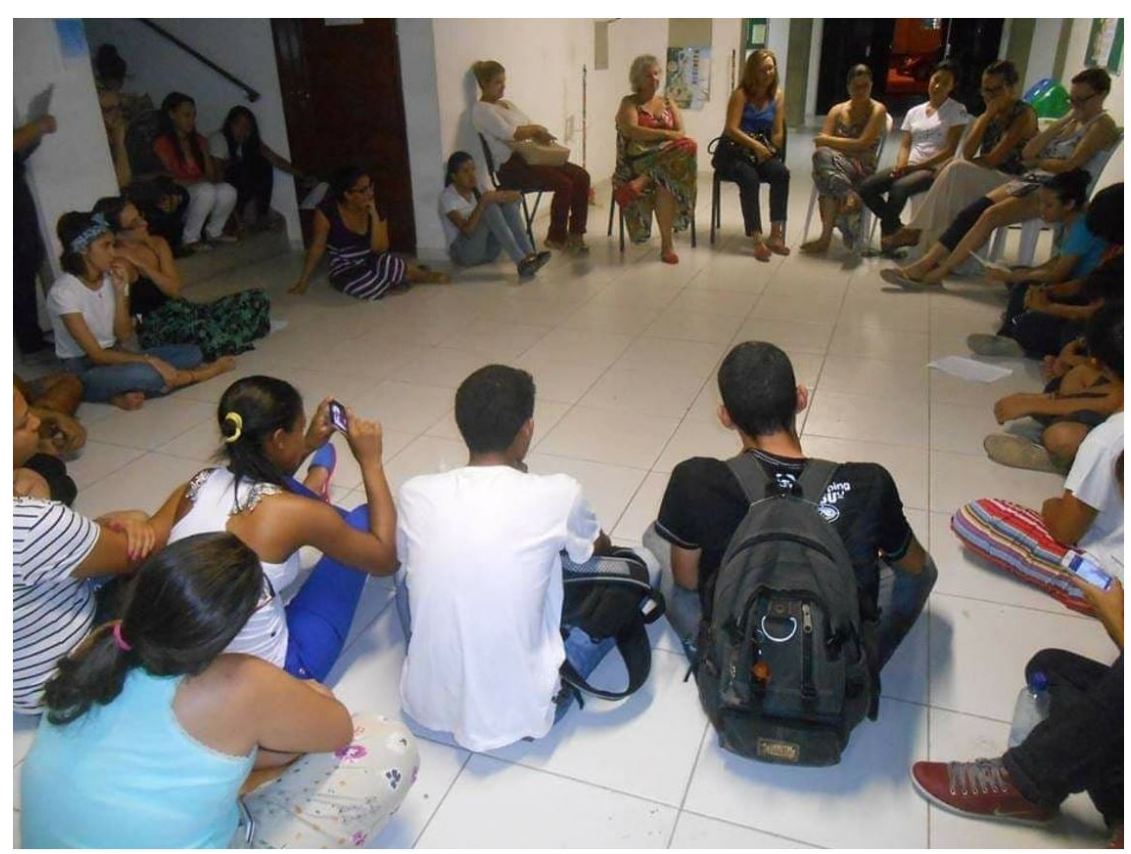

Figura 3. I Varal Poético. 
O segundo varal intitulou-se "Lou(CURE)se, a sua loucura parece um pouco com a minha!" e envolveu discussóes acerca da luta antimanicomial para promover aproximaçóes dos participantes com as vivências de pessoas com transtornos mentais e com a importância do cuidado produzido nos serviços substitutivos de atenção à saúde mental. O terceiro teve como tema a Educação Popular, com a chamada "Educa-te: só assim poderá transformar”, e construiu-se o debate sobre as práticas educacionais tradicionais, baseadas na reprodução de informações acumuladas, em contraposição a práticas dialógicas e potencialmente transformadoras da realidade, propostas pela Educação Popular e adotadas pelo projeto.

Os princípios da Educação Popular possibilitam que o processo educativo ocorresse com o desenvolvimento da consciência crítica e reflexiva sobre a realidade a ser transformada e com o empoderamento dos sujeitos para as conquistas de seus direitos sociais, culturais e políticos. Pensar na transformação social com base em uma educação livre, libertadora, social e politicamente responsável e fundamentada na teoria dialógica, com a integração dos educadores e educandos nesse processo, vai de encontro ao modelo de educação tradicional, pois problematiza o autoritarismo e dispóe do compromisso com a diversidade e emancipação do sujeito no processo pedagógico (Freire, 1967).

O quarto varal trouxe como temática "Todas as formas de amor" e fomentou a discussão sobre sentimentos de resistência, opressão e empatia que compóem as diversas possibilidades de amar. Nos diálogos predominou o debate sobre o amor $\mathrm{LGBT}^{3}$, com reflexôes sobre a discriminação vivenciada por essa população. O quinto varal intitulou-se "As cores e formas de ser e tornar-se mulher", em que as participantes discutiram sobre essa questão baseadas em poesias e frases de mulheres como Nise da Silveira, Cora Coralina e Simone de Beauvoir ${ }^{4}$ (Figura 4).

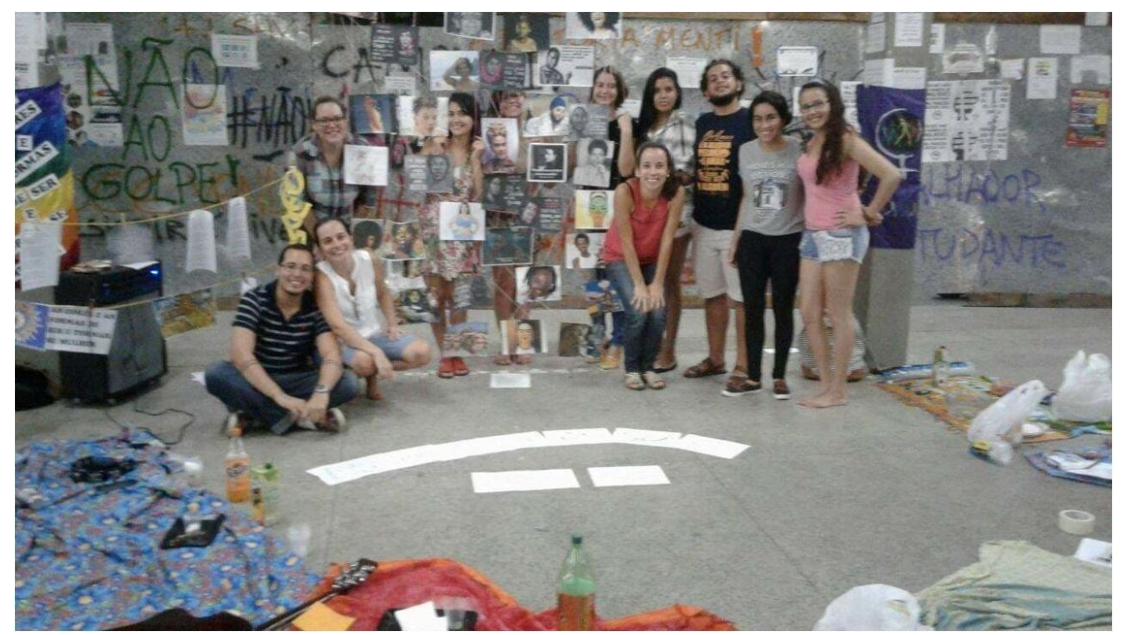

Figura 4. Varal Poético.

${ }^{3}$ LGBT: Sigla destinada à população de Lésbicas, Gays, Bissexuais, Travestis, Transexuais ou Transgêneros (Brasil, 2013). ${ }^{4}$ Nise da Silveira foi uma psiquiatra que revolucionou o tratamento da loucura no Brasil (Itaú Cultural, 2018). Cora Coralina foi poetisa e contista, considerada uma das maiores escritoras brasileiras; Simome de Beauvoir foi escritora, filósofa, integrante do movimento de existencialismo francês e teve papel fundamental na construçáo do feminismo (eBiografia, 2000a, 2000b). 
Os varais poéticos contaram com a presença de membros da comunidade acadêmica (estudantes, técnicos e professores) de diversos Centros de Ensino da universidade, com participaçáo menos expressiva da comunidade externa, que se deu somente no segundo varal, do qual participaram usuários de um Centro de Atenção Psicossocial, sendo um deles poeta.

Buscava-se a valorização da afetividade, da sensibilidade, da expressão de si e da escuta, para exercitar a aproximação humanizada e respeitosa entre as subjetividades dos participantes e das pessoas com as quais viriam a se encontrar em sua formação e atuação profissional. Nessas vivências, os participantes podiam fazer atividades das quais gostavam, falar abertamente sobre si e colocar diversas de suas angústias e inquietaçóes advindas de suas experiências internas e externas à academia, em um espaço de aceitação e acolhimento de si e do outro. As açóes desenvolvidas contribuíam para a exploração da criatividade e inventividade e para a produção autêntica dos estudantes e demais participantes, que se expressavam de formas não comumente utilizadas nas atividades acadêmicas.

Nestes varais era feita a produção de cuidado e sentido de vida (P1).

Eram desenvolvidos afagos e afetos entre as e os participantes (P9).

Era um ambiente com perspectivas totalmente horizontais, em que todxs possuiam voz e vez. Foram momentos únicos, repletos de trocas de experiências e de grande aprendizado. Houve exposiçóes de vídeos, fotos, poemas, poesias e incriveis histórias de vidas. Foram dias que ficarão para sempre em meus pensamentos e no meu coração (P15).

O projeto também realizou intervenções em eventos como a comemoração dos 60 anos da universidade, com leitura coletiva de poesia e construçáo de um mural sobre a poesia do cotidiano. Foi concedida pela docente coordenadora uma entrevista para o jornal da universidade, na qual se abordou a poesia como ferramenta para sensibilização do olhar, e foram apresentados trabalhos no Encontro Nacional de Extensão, nos eixos temáticos da Cultura, Saúde e Educação; na IV Amostra Nacional de Experiência e Reflexão em Extensão Popular; e no XV Encontro Nacional de Docentes de Terapia Ocupacional (Figura 5). 


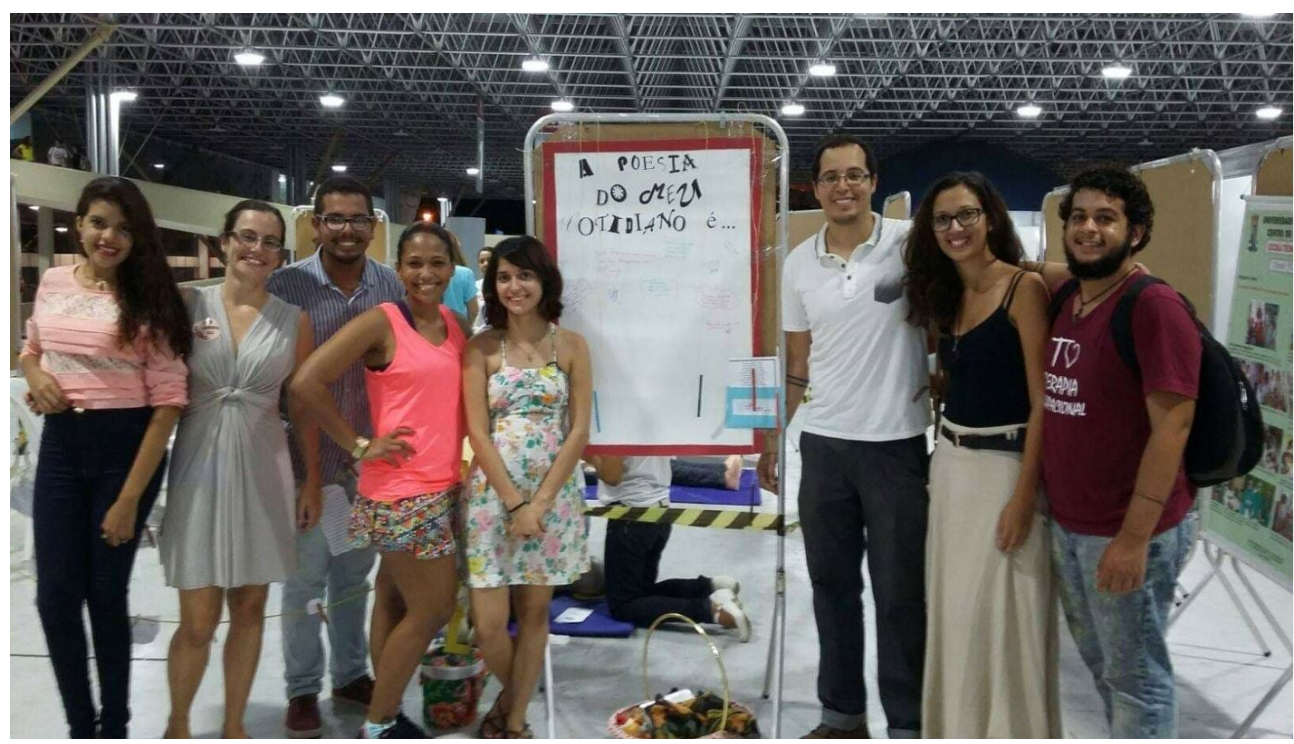

Figura 5. Intervenção no evento em comemoração aos 60 anos da universidade.

Para aumentar a visibilidade e a repercussão do projeto, criaram-se uma página e um grupo em uma rede de comunicação social, em que se produzia o compartilhamento de poesias, vídeos, textos e reflexóes acerca de diversos assuntos. Neles, realizava-se também a divulgação dos eventos do projeto, com possibilidade de devolutivas das pessoas que deles haviam participado, com suas impressóes e sentimentos vivenciados nos encontros.

Em 2016, com o afastamento da docente idealizadora e coordenadora, o projeto de extensão passou a ser coordenado por outra docente que com ele já colaborava, com continuidade da participação dos outros dois docentes colaboradores, em conjunto com nove estudantes, uma do curso de Direito e oito do curso de terapia ocupacional. Em tempo, alguns ajustes foram realizados no projeto, como a decisão de não o submeter novamente ao PROBEX, dando continuidade à sua execução na proposta de FLUEX. Nesta nova fase, ocorreu o evento intitulado "Raízes da opressão", que consistiu na distribuição de cartazes interativos pelo prédio do Departamento de Terapia Ocupacional, nos quais a comunidade que circulava no local pôde escrever livremente e de forma anônima quais opressóes sofriam no cotidiano. Após esta ação, estudantes procuraram membros do projeto, relatando acontecimentos recorrentes de opressão de diversos tipos, principalmente racismo e homofobia, ocorridos no âmbito do departamento entre alunos e professores e entre os professores.

$\mathrm{Na}$ sequência, ocorreu uma Roda de Conversa, disparada pelos seguintes recursos audiovisuais: Vídeo do Youtube "Racismo no Brasil - Preto no Branco - Nem tudo é o que parece"; e Curta-metragem "Pode me chamar de Nadî", tendo em vista que a questáo do racismo se destacou nos cartazes e denúncias realizadas. Dois docentes do curso de terapia ocupacional mobilizaram alguns períodos letivos, colocando esta ação da extensão como atividade da disciplina. A coordenação de terapia ocupacional acompanhou a ação e seus desdobramentos, com base nas denúncias e problematizaçóes colocadas no âmbito do curso. Após isto, realizou-se outra roda de 
conversa para discutir a opressão como problemática social, com a presença de estudantes e docentes deste e de outros cursos.

A segunda ação ocorreu durante a semana de comemoração do dia do terapeuta ocupacional e consistiu em intervençóes interativas e artísticas fixadas no Campus I da universidade. Em locais de convivência e maior trânsito de pessoas, foram colocados cartazes, com uma caneta e a pergunta "Para você, o que é terapia ocupacional?". Nos dias dos eventos alusivos ao aniversário da profissão, os cartazes com as respostas foram expostos no Departamento de Terapia Ocupacional. Como devolutiva aos locais onde haviam sido instalados os primeiros cartazes, fixaram-se novos cartazes que apresentavam uma definição de terapia ocupacional. Essa proposta foi relacionada à contribuição do projeto para a divulgação da profissão, tendo em vista a falta de conhecimento e reconhecimento por parte de outros cursos e, em geral, pela comunidade acadêmica acerca desta. Um dos participantes relatou que esta atividade possibilitou "[...] mostrar a terapia ocupacional com uma nova ótica [cultural]" (P10).

Nesta mesma perspectiva, foram criados folders com uma definição de terapia ocupacional para distribuiçáo à comunidade acadêmica. Em tempo, a equipe de execução realizou uma ação em um Simpósio Estudantil ocorrido na instituiçâo, tendo como base a mesma proposta: foi construída uma teia de lã com fotos de terapeutas ocupacionais e outras pessoas que influenciaram o desenvolvimento da profissão; fixaram-se balóes em outros espaços no campus contendo questionamentos acerca da terapia ocupacional, com as respectivas respostas dentro dos balóes.

Nesta etapa do projeto, verificaram-se modificaçóes nas estratégias de intervenção e nas atividades propostas, passando a ser realizadas rodas de conversas sobre problemáticas sociais como violência contra a mulher, empoderamento feminino e opressões vivenciadas na academia (LGBTfobia, feminismo, luta da população negra), trazendo para debate a importância do fortalecimento dos movimentos sociais dentro e fora da universidade, o que já vinha de certa forma ocorrendo nos varais poéticos. Permaneceu, também, a essência do caráter coletivo e democrático da extensão universitária, com empoderamento de todos os envolvidos.

Eram atividades que impulsionavam um pensamento reflexivo. Os temas eram os mais variados possiveis. As formas de ensino-aprendizagem se davam através de métodos que contribuiam para agregar ainda mais estudantes ao projeto. As atividades proporcionaram a participação de todos os presentes, desde que os mesmos se sentissem à vontade para se colocar (P9).

O projeto sempre foi algo nosso, coletivo. A construção das atividades acontecia em grupos, iniciando pela "nossa" sala, seguindo aos corredores, entornos, departamentos, universidade e sociedade. Faziamos diálogos coletivos sobre diversas temáticas que perpassavam o ser, suas ocupaçōes, dimensóes, contextos e cuidados. Problematizávamos temáticas diversas, criamos intervençóes regadas de poesias, artes, conversas, sons e lágrimas. Construimos varais poéticos, cartazes, murais e atividades expressas de artes (P13).

Nas reuniōes de execução, além do planejamento, preparação e avaliação das ações, passaram a se formalizar momentos de estudos nos quais diferentes textos e temas 
foram abordados, com a mediação de terapeutas ocupacionais convidados: a produção de Fanzine como meio de expressão e recurso para a terapia ocupacional no campo social; a Teoria das janelas quebradas, do Blog Justiça para Todos; e a Educação popular.

O projeto Extensão Universitária em Poesia Ocupacional finalizou suas atividades em 2016, com um piquenique no gramado no Centro de Ciências Humanas, Letras e Artes da instituição, colocando a necessidade de novos projetos e açóes que viabilizassem assuntos pouco discutidos no meio acadêmico, principalmente questóes sociais como as supracitadas.

$\mathrm{Na}$ sua concepção, o projeto de extensão intencionava realizar açôes que sensibilizassem os membros das suas equipes de execução e os estudantes que participassem das atividades ofertadas - em especial de cursos que realizassem assistência a pessoas nos campos da saúde, educação, cultura e social, o que foi contemplado. A segunda etapa seria o desenvolvimento de açóes, também ligadas à poesia e a diversas possibilidades de manifestaçóes artísticas e culturais, desses extensionistas em serviços e/ou equipamentos pertencentes aos campos anteriormente citados, diretamente com as pessoas que os frequentassem, o que não chegou a se concretizar.

\subsection{Motivaçóes para ingresso no projeto}

Os relatos dos participantes da pesquisa apresentaram motivaçóes diversas para ingresso no projeto, sendo uma parte minoritária relacionada à necessidade de cumprir os componentes flexíveis exigidos para a conclusão do curso. A maior parte deles interessou-se pelo projeto devido à proximidade com as coordenadoras, à afinidade com a proposta e à busca de experiências relacionadas à produção de um cuidado humanizado com base na sensibilização dos estudantes.

Primeiramente, pela confiança que sempre tive "nxs professorxs" que decidiram coordenar o projeto e por acreditar na proposta que o projeto apresentava (P15).

O projeto pedagógico e a proposta de atrelar poesia ao cotidiano e ao cuidado em saúde (P7).

O Poesia veio com uma proposta singular dentro do Departamento de Terapia Ocupacional, este me chamou a atenção pela forma que estava propondo o cuidado e a produção de vida (P14).

Neste mesmo sentido, outros respondentes acreditavam que o projeto acolhia as pessoas e as empoderava para protagonizar sua formaçáo como produtores de um cuidado humanizado e agentes de transformação social, além de possibilitar a aproximação sensível com os cotidianos das pessoas atendidas pela profissão.

A proposta do projeto parecia ser voltada à natureza humanistica, ou seja, à compreensão do estudante com ator social e agente de transformação (P5). 
Fazia-nos acreditar no potencial que poderiamos ter e temos enquanto futuros profissionais que nos envolvemos com os mais complexos, peculiares, lindos e também poéticos cotidianos das outras pessoas. Na realidade, eu sentia que o projeto seria extraordinário pela energia que emanava! (P15).

Outra motivação que gerou o interesse de alguns participantes foi a possibilidade de compreensão do ser humano e da profissão em suas dimensóes cultural, social e educacional, com base na proposta de açóes profissionais contextualizadas e sensíveis às diferentes realidades vivenciadas pelas pessoas atendidas pela terapia ocupacional.

As motivaçôes para minha participação no projeto foram diversas. A possibilidade de refletir sobre outras realidades; alinhar conhecimento científico com conhecimentos empiricos entendendo que o processo saúde doença vai além de fatores ambientais e biológicos (P9).

\subsection{Princípios estruturantes e metodologias de funcionamento}

As respostas dos participantes sobre suas motivaçóes para entrada no projeto apontaram que, antes mesmo do seu ingresso, os estudantes haviam compreendido, ao menos parcialmente, os princípios que o estruturavam. Os relatos a seguir revelam que os participantes, ao discorrerem sobre as atividades desenvolvidas, também conseguiram identificar os princípios e metodologias por ele adotados, como a formação profissional sensível e humanizada, o uso de tecnologias leves, a aproximaçáo com a arte e a poesia, a horizontalidade das relaçóes entre docentes e estudantes e entre terapeutas ocupacionais e pessoas atendidas pela profissão.

A utilização das tecnologias leves, princípio estruturante e recurso metodológico do projeto durante a maior parte de sua vigência, foi identificada por parte dos respondentes como um dos meios para proposiçáo de novas formas de aprender e ensinar, mais flexíveis e ampliadas, possibilitadas também pelo uso da poesia e das artes.

Os aspectos positivos do projeto estavam em torno do ato de educar, ensinar e refletir; a busca pela ruptura de modelos engessados, reducionistas e positivistas, como também a valorizaçáo do uso de tecnologias leves, da poesia e das artes (P13).

As tecnologias leves baseiam-se no acolhimento, escuta e produção de vínculo e possibilitam a produçáo do cuidado orientada pela horizontalidade entre os profissionais e as pessoas atendidas, ultrapassando os modelos assistenciais mecanicistas e fortalecendo as práticas humanizadas em saúde. O projeto de extensão propunha a formação baseada nessas tecnologias, trabalhadas durante as atividades, no sentido de instrumentalizar os participantes para acolher integralmente as pessoas que viriam a atender e mobilizar sua capacidade inventiva e criativa (Merhy, 2005; Siegmann, 2006).

Os participantes, de modo geral, consideraram que o uso da arte e da poesia foi um dos fatores que os fizeram permanecer no projeto e possibilitou o exercício do 
pensamento reflexivo, da empatia, da sensibilidade à diversidade e da transformação na produção do cuidado.

Despertam criatividade e empatia, distanciam estereótipos, colocam novas formas de se pensar relaçóes, de promover cuidado, de compreensáo de mundo e do mundo do outro (P14).

Ao problematizar a vida acadêmica, permeada por cobranças, padronizaçóes, distanciamento das expressóes emocionais e afetivas e superficialidade das relaçóes, alguns colaboradores reconheceram a arte como um recurso simples, que não segue padróes e possibilita a liberdade de expressão e de ação e experiências acadêmicas inventivas e criativas, valorizando os sentimentos e potências que coabitam cada sujeito e imprimindo leveza ao cotidiano.

$A$ arte e em especial a poesia tem uma simplicidade e uma complexidade na forma de se estruturar. Como a vida e os nossos fazeres, tão simples e tão complexos (P1).

$A$ arte é livre, tem cores e formas para qualquer corpo. Acredito que naqueles momentos o importante era que nos conectássemos da maneira mais livre $e$ verdadeira possivel, deixando um pouco de lado o peso do jaleco (P7).

Nunca vivi a poesia, mas vivenciei muito a arte. A arte é a expressão da alma humana, do artista, da pessoa que a desenvolve (P10).

Protocolos, seminários, pressão psicológica, notas, padröes, tudo isso é comum e mecânico, creio que é preciso tornar-nos mais leves, menos "robotizados" e o que mais pode proporcionar isso se não a arte? A arte não segue padróes, tudo pode tornar-se poesia, inclusive nossos pesados dias em busca de um diploma, por isso acredito que estes meios são a melhor forma de expressáo individual e direta ou indiretamente contribui para dias mais leves (P11).

A aproximação com a poesia e a arte tinha como proposta valorizar e possibilitar a produção autêntica dos participantes e a manifestação de seus desejos, sentimentos e opiniōes, com base na compreensão de que a arte e a cultura são libertadoras ao expressar afetos e ressignificar vidas (Andrade et al., 2016).

Meira \& Silva (2013) apontam que a arte vai além de uma técnica e/ou recurso, tratando-se de um fenômeno social que promove elos com a vida cotidiana e provoca relaçóes humanas mais sensíveis, tanto para quem a produz quanto para quem a aprecia. A utilização da arte nos cenários acadêmicos deve considerar o cotidiano interno e externo a esses espaços, pois "[...] não é possível ver alguém por inteiro, entender o aluno, como ele pensa, significa e expressa o mundo, se retirarmos tudo o que o caracteriza no seu dia a dia" (Meira \& Silva, 2013, p. 54).

A proposta de atuar na interface com a arte e a cultura oportunizou que os estudantes experimentassem uma posição inventiva e fossem acolhidos na construção de outras possibilidades de manifestação para além da verbal e escrita, condição 
fundamental à sensibilização para o cuidado com o outro (Castro et al., 2009; Lima et al., 2009).

A utilização da poesia, compreendida como um movimento que acolhe o vazio, os gestos, os sentidos e as falas (Siegmann, 2006), não se relacionava apenas à elaboração de textos poéticos, mas, principalmente, à sensibilização do olhar e ao compartilhamento de experiências poéticas e singulares de cada sujeito. A poesia, nesse contexto, representa uma possibilidade de educaçáo das percepçóes e dos sentimentos, podendo também participar da educação imaginativa, em um processo de libertação dos estereótipos produzidos pelas mídias-máquinas, oportunizando-se encontros e diálogos criadores de identificações, identidades e diferenças (Antônio, 2013).

Antônio (2013) fala da necessidade de poetizar o pedagógico, no sentido de transformar poeticamente a relação entre ensinar e aprender, para produzir a sensibilização do olhar diante de si, do outro e das infinitas possibilidades de construção da existência humana. Para o autor, os processos educacionais devem mobilizar aspectos para além da inteligência, tecendo-se novas formas de aprendizagem voltadas ao exercício da sensibilidade, que sejam dialogadas e baseadas na produção de sentidos que emergem nos encontros. O projeto, desde sua concepçáo, adotou como princípio que a formação profissional, em especial de terapeutas ocupacionais, deve possibilitar espaços de sensibilização do olhar do estudante para si, para o outro e para as diversidades, o que passa pela construção de propostas em que este vivencie e reflita sobre a atividade humana em sua complexidade e multiplicidade de produção de sentidos.

Pensar na extensão universitária como possibilidade de criação de estratégias conjuntas para transformação social, entre universidade e comunidade, também é pensar no estudante como "ator social e agente de transformação", como relatado por P5, o que se constituía como um dos princípios centrais do projeto. Para Freire (1987), o educador precisa se identificar com o educando, para que haja democratização do poder nas relaçóes e decisóes em torno do processo educativo. Outro princípio adotado era a horizontalidade das relaçóes entre docentes e estudantes, acreditando-se que somente dessa maneira estes poderiam se tornar protagonistas de seus processos educacionais e atuar de forma transformadora na sociedade.

\subsection{Contribuiçóes das atividades ofertadas}

Nesta categoria, foram incluídos os conteúdos relacionados às açóes desenvolvidas, no que diz respeito às contribuiçóes para as pessoas que delas participaram, com base na ótica dos colaboradores da pesquisa. Um dos quinze respondentes considerou não ter havido êxito nas intervençôes, o que se contrapóe às percepçôes dos demais, nas quais se observou o reconhecimento de contribuiçóes dos varais poéticos e das rodas de conversa para as pessoas que a eles compareceram. Nos relatos, verifica-se que eles se colocam como participantes das atividades e não somente como executores das propostas, visto que suas consideraçóes se estendem às suas próprias experiências.

As contribuições elencadas dizem respeito à sensibilização do olhar para si e para o outro, escuta, amorosidade, acolhimento, produçáo do pensamento crítico, transformação de si e qualificação do cuidado ofertado. 
Entendendo que fui participante desse projeto, posso relatar o quanto ele contribuiu para a profissional-pessoa que sou hoje. Este projeto veio como uma ferramenta potencializadora do cuidado e do respeito. Vozes foram cantadas, ouvidas e se fizeram ouvir, construimos pensamentos criticos, mas também repensamos as criticas humanas, enxergamos e percebemos o ser em suas dimensóes possiveis e intangiveis, produzimos, construimos, e disseminamos conhecimentos, amor e acolhimento (P14).

Poder fazer parte de um projeto que nos questiona o tempo todo, os motivos pelos quais estamos sendo tão duros conosco é também a possibilidade de reinvenção no sentido de fazer saúde e para quem fazer (P7).

Não tem como você entrar no Poesia e sair do mesmo que jeito que você entrou! No projeto aprendemos a olhar as coisas com uma leveza muito positiva (P3).

Acho que assim como eu, cada um foi tocado. Ou por alguma arte utilizada ou experiência ouvida (P12).

A sensibilidade que permeava os encontros foi ressaltada por alguns respondentes, no que diz respeito ao empoderamento das pessoas com base na aceitação de suas singularidades, da valorização de suas falas e da afetividade desenvolvida entre os participantes, o que, por vezes, fez com que as atividades propostas se constituíssem como espaços de promoção e produção de saúde para os participantes.

Proporcionava um espaço de discussóes que acolheram sujeitos e suas diversidades. Rompendo barreiras universitárias e estigmas sociais (P13).

Eu via a forma como as pessoas saiam dos momentos dos varais e de como aquilo era importante para elas, em poder saber que estão sendo escutadas e que aquilo que elas estão falando estava sendo levado a sério (P1).

Tais produçóes permitiam a promoção de saúde, o acolhimento de si e do outro, o olhar mais humanizado e o vinculo (P14).

Os relatos revelam que os participantes compreenderam que a abordagem da produção de cuidado adotada nas atividades do projeto relacionava-se com o respeito a todos os modos de vida, o empoderamento dos sujeitos e a sensibilidade ao silêncio, à fala e aos gestos, no sentido de que o cuidado exige envolvimento e responsabilidade afetiva com o outro (Coelho \& Fonseca, 2005). O trabalho em saúde não deve ser produzido apenas com base na utilização das tecnologias leve duras - saberes estruturados como a clínica médica, a psicanalítica e a epidemiológica, e duras recursos materiais, como máquinas, normas e estruturas organizacionais, devendo se configurar também com o desenvolvimento de procedimentos técnicos baseados nas teconologias leves, que envolvem as relaçóes, os encontros, o acolhimento, a escuta e a subjetividade (Merhy, 2005).

No que diz respeito à promoção e à produção de saúde possibilitada a pessoas que compareciam às atividades do projeto, acredita-se que isto foi possível devido ao 
compartilhamento de histórias de vida, ao estabelecimento de relaçóes afetivas e ao envolvimento de uns com os outros em suas dimensóes sentimentais, cognitivas, comportamentais, éticas e morais, sem a produção ou reprodução de rótulos, e com a identificação dos sujeitos como seres desejantes e criativos, que dessa forma se sentiam aceitos e cuidados (Siegmann, 2006; Cancherini et al., 2012).

$\mathrm{O}$ projeto buscou, ainda, promover espaços de abertura ao exercício do direito à participação, com base em relaçóes horizontais e nas trocas entre os participantes das açóes realizadas, o que provocou um deslocamento para o sensível e contribuiu, para além da produção de saúde, para a produção de cidadania (Inforsato et al., 2017).

\subsection{Contribuiçóes para a formação e atuação profissional}

Os participantes foram questionados sobre as contribuiçóes do projeto para sua formação e, em separado, para sua atuação profissional, no caso dos que já haviam concluído o curso. Os resultados revelaram que o projeto contribuiu para a atuação nos campos de estágios e atividades curriculares exercidas durante a graduaçáo, bem como para a atuação profissional.

Ainda não cheguei na vida profissional, mas posso dizer que nos cenários de práticas e nos estágios pude resgatar muita coisa que aprendi desse tempo e pude desenvolver nas práticas (P1).

Ainda não estou trabalhando, mas no campo de estágio eu sempre me lembro do projeto, a leveza que o projeto passa de como encarar os problemas no dia a dia (P3).

Pensar a terapia ocupacional que construi junto à equipe do Poesia, é pensar numa atuação que olhe dentro do olho e acolha o que dele vier. É entender que os processos de adoecimento e de cuidado precisam estar conectados com o desejo e o respeito que é lidar com alguém que se encontra necessitado (P7).

Esse exercício de enxergar o sujeito em todas as suas dimensóes e estar apto a acolher o que for por ele colocado é importante para que se produza uma atenção generalista, integral e intersetorial, na qual o terapeuta ocupacional esteja sensível às singularidades do sujeito e aos diferentes modos de exercer a profissão, em todos os seus campos de atuação. Novamente, evidenciou-se a extensão como possibilidade de proposição de açóes que promovam rupturas com modelos enrijecidos de formação a atuação profissional. Dois respondentes que já se encontram em exercício profissional relataram que:

O tipo de formação proposto pelo projeto apresentou-se indissociável na minha atuação. Assim como, a busca pela ruptura de práticas tecnocratas, sistemáticas e frias, que percorreram formação e atuação, [...] pude buscar diante dos enfrentamentos, atuar nesses espaços em uma perspectiva integral, prezando e priorizando acolhimento, escuta e clinica ampliada. Além de almejar um cuidado que ultrapassasse o olhar técnico e reducionista, e alcançasse familias, ambientes e interfaces com educação, justiça e inserção/reinserção social. Mesmo 
que o esforço por esse tipo de prática também carregasse uma conotação de resistências e lutas que advêm da formação (P13).

Contribuiu para eu atuar no CREAS $S^{5}$ onde tive muito contato com pessoas que estavam em vulnerabilidade social e passei a vivenciar na prática o que vi um pouco na teoria (P10).

Parte dos colaboradores relatou que o projeto de extensão contribuiu no sentido de valorizar as histórias de vida do outro, ter empatia, acolher o sofrimento e ouvir sem julgar.

Me impulsionou a refletir sobre a importância da empatia nas minhas açôes; a entender que somos seres complexos, por isso, não devemos reduzir ninguém a termos, categorias, etc. Ouvir, apenas ouvir. Não tentar formular uma resposta enquanto o outro ainda esteja a se colocar, a expor algo (P9).

A experiência nele me fez refletir na prática...quando ouço o outro, sem julgar nem desmerecer o que a pessoa está falando, valorizando cada palavra, ou cada silêncio. Enfim, a confiança que essa pessoa está depositando ao relatar sua vida. Acho que é isso! (P12).

Outra contribuição para a formação profissional diz respeito às sobrecargas do cotidiano acadêmico, com relatos de que ele se tornou mais leve e ganhou outros significados com as experiências vivenciadas.

O projeto acolheu os sofrimentos causados pela sobrecarga da academia, não só meus, mas de todos que tiveram a oportunidade de participar, e tornou esse processo bem mais leve ( $\mathrm{P} 2)$.

Contribuiu sim. Poder encarar com mais leveza o cotidiano, a ter mais empatia com o outro (P3).

Escutar, observar e viver o cotidiano passou a ser diferente. As coisas começaram a ter sabor dentro da terapia ocupacional para mim (P7).

O Poesia Ocupacional me abriu novos horizontes e foi transformador na minha jornada. Depois do Poesia, eu jamais olharei para as experiências cotidianas como antes (P15).

A ressignificação da atuação profissional também foi apontada por parte dos respondentes, com base na percepçáo de que o projeto propunha a construçáo de práticas integrais de atenção em terapia ocupacional, baseadas na empatia e no respeito à diversidade humana. Isso exige mudanças na formação profissional, entre elas a adoçáo de abordagens baseadas na centralidade dos sujeitos atendidos e no

${ }^{5}$ O CREAS (Centro de Referência Especializado de Assistência Social) é UMA unidade pública da política de Assistência Social destinada ao atendimento de pessoas e famílias em situação de risco social ou de violação de direitos (Brasil, 2015). 
protagonismo dos estudantes, que devem ser formados para atuarem como agentes de transformação social, na produção de relações humanizadas e sensíveis.

Contribuiu para que eu entendesse que o processo saúde-doença está além de fatores biológicos e ambientais, como citado anteriormente. Me impulsionou a refletir sobre a importância da empatia nas minhas açôes (P9).

Expandir formas criativas de cuidar do seu "eu" profissional e pessoal com um olhar atento para as diversidades dos sujeitos. Valorizando a escuta, o vinculo, o diálogo e horizontalidade das relaçóes. Além do despertar para o poetizar-me, que não é a formação de poemas e poetas, mas o permitir-se aflorar em si suas dimensóes cuidadoras e poéticas (P13).

O projeto foi na época, um questionário vivo onde a todo instante eu repensava e sentia de maneira fluida tudo que vinha vivendo em sala de aula [...]Era doce o modo como a escuta podia contribuir na evolução do atendimento, era amargo pensar que muitas vezes nossa atuaçáo ainda trazia traços enrijecidos de um fazer saúde biomédico. Nesse sentido, [...] as possibilidades de abordagem em saúde se expandiram e se expandem pois o projeto, mesmo hoje, ainda faz parte do que acredito ser uma terapia ocupacional sensibilizada e comprometida com os atravessamentos alheios (P7).

O projeto propunha a superação da formação de profissionais da saúde baseada no modelo biomédico, voltado a ações exclusivamente curativas e à remissão de sintomas, com a construção do olhar e pensamento crítico e sensível que deve nortear as intervençóes direcionadas à compreensão dos sujeitos e seus modos de vida, em seus contextos culturais, sociais, éticos e políticos (Furlan et al., 2014).

Os relatos dos participantes revelaram que, com base nos próprios fazeres e do compartilhamento de experiências referentes ao fazer humano, internas e externas à formação profissional, ocorreu um processo de sensibilização do olhar para o outro e uma ampliação da compreensão acerca da complexidade envolvida nas infinitas formas de realização e significação das atividades humanas. $\mathrm{O}$ projeto intencionou colaborar para uma formação profissional crítica, reflexiva e transformadora, que contemplasse o aprender, o conviver, o ser e o fazer e permitisse a criação de formas sensíveis de comunicação e de relações sociais, necessárias à atuação nos campos de prática (Castro et al., 2016; Joaquim et al., 2016).

\subsection{Avaliaçáo do projeto}

Nesta categoria serão destacados os aspectos positivos e negativos do projeto, bem como as considerações dos participantes sobre a contemplação de suas expectativas iniciais. Boa parte dos respondentes sinalizou que as dificuldades encontradas durante a extensão relacionavam-se ao horário das reuniôes de planejamento, que, durante quase toda a sua vigência, realizaram-se em fins de tarde, com a intenção de possibilitar a participação de estudantes de todos os períodos do curso. Por se tratar de um curso integral, muitos participantes chegavam às reunióes sentindo-se cansados, após um dia inteiro de atividades acadêmicas, ou não conseguiam permanecer até o fim delas por 
residirem em locais distantes da universidade. Além disso, o tempo direcionado ao planejamento não era suficiente para concretizar parte das açóes propostas.

Como fator negativo o horário não era muito bom e durava pouco tempo e bastante coisas ficaram no papel justamente por falta de tempo para pôr em prática (P6).

Em decorrência do horário (as reunióes iniciavam à tardinha, ou noite) e por alguns participantes residirem longe, não podiam permanecer por muito tempo em algumas reunióes $(\mathrm{P} 10)$.

Outros aspectos negativos apontados, sendo o primeiro deles decorrente de uma avaliação positiva do projeto, foram o término do projeto e o fato de este não ter exercido atividades externas à comunidade acadêmica.

Pontos negativos pra mim foi ter acabado, permanecer ainda nos muros da universidade (P1).

Enquanto negativo, só a tristeza de saber que o projeto está parado (P7).

Náo me recordo de pontos negativos. Porém almejo o retorno das atividades do projeto de maneira concreta e que este se consolide como um movimento social e educacional (P13).

Não acredito que seja um aspecto negativo, mas sim um desejo, que o projeto tivesse ganhado mais força para ir além dos muros acadêmicos (P14).

Um desafio apontado por alguns dos participantes, também verificado nos registros das atividades, diz respeito à comunicação e ao compromisso de alguns membros das equipes de execução. Um dos colaboradores sinalizou que o compromisso insuficiente com as atividades devia-se à "[...] liberdade que se tinha no projeto" (P2), no que diz respeito à flexibilidade e às reduzidas cobranças por parte das coordenadoras.

Infelizmente o último encontro não foi como se havia planejado, talvez esse também tenha sido um ponto negativo, faltou diálogo, mas acredito que já era o desgaste do semestre (P12).

Como a motivação principal de alguns alunos para ingresso no projeto foi o cumprimento de componentes flexíveis exigidos para a conclusão do curso, pode não ter ocorrido por parte deles a identificaçáo e afinidade com o projeto, o que explica em parte o desinteresse e o insuficiente comprometimento com algumas das atividades propostas, justificados por um cotidiano acadêmico sobrecarregado.

No que diz respeito aos aspectos positivos, diversos relatos enunciaram que as propostas e produçôes desenvolvidas durante a vigência do projeto foram significativas e basearam-se na coletividade, respeito, afetividade, sensibilidade e diversidade de temáticas e de pessoas. 
Positivos: Diferentes pontos de vistas, variados temas abordados, escuta, companheirismo, leveza, coletividade (P11).

O projeto não se configurou como um espaço em que os docentes "devessem" atender as demandas dos alunos/participantes e sim que fosse criado um lugar que passou a ser nosso, do coletivo. Em que as açôes eram pensadas e realizadas acolhendo as diversas opinióes e sugestôes, dos alunos, docentes e participantes. Então, não tinham somente expectativas a serem cumpridas e sim a construção dos nossos ideais (P13).

Enquanto aspectos positivos evidencio a forma como os debates eram construidos, permitindo e ressaltando a importância da colaboração de todos, assim como também as temáticas que eram sempre muito relevantes, além disso destaco a energia e afeto contidos nos momentos compartilhados em grupo (P14).

Observou-se que boa parte dos respondentes avaliou que as experiências no projeto promoveram novos olhares e vivências a respeito da formação profissional, no sentido de se perceberem como agentes de transformação e produtores de cuidado, e de ampliarem sua capacidade de produzir novos sentidos e aberturas para modos de fazer e viver seu cotidiano acadêmico.

Consegui entender muito mais aquilo que estava me inquietando, que era o silenciamento das pessoas diante do cotidiano frenético, corrido. E ter esse espaço de parada, reflexáo e escuta era o cano de escape (P1).

$\mathrm{Na}$ verdade ele me deu expectativas. Isso foi importante no meu entendimento enquanto humana, enquanto alguém que se propóe a cuidar e alguém que deseja sentir (P7).

No projeto encontrei calmaria dentro de um bloco em que encontrávamos diversos "problemas" para resolver, pude encontrar pessoas fortes e aprender muito com suas vivências, pude enxergar que cuidar de mim e cuidar do outro andam pelo mesmo caminho e que para chegar a toda comunidade precisamos começar pelos centros acadêmicos tornando-os espaços de trocas e vivências (P14).

Um projeto lindo e que nos permitiu visitar nosso lado mais humano e sensivel, fazendo com que aprendêssemos com o mais complexo e, ao mesmo tempo, simples cotidiano daqueles que nos cercam e daqueles que entramos em contato. Foi uma experiência incrivel e inexplicável (P15).

\section{Consideraçóes Finais}

A pesquisa apresentada elucidou a potência dos afetos, da amorosidade, da arte, da poesia e da cultura para a formação em terapia ocupacional voltada a práticas sensíveis e humanizadas de atenção. Seus resultados mostraram, de forma geral, os princípios condutores e estruturantes das proposiçôes e intervençóes desenvolvidas pelo projeto: o uso de tecnologias leves, a aproximação com a arte e a poesia, a horizontalidade das relaçóes entre docentes e estudantes e entre terapeutas ocupacionais e pessoas 
atendidas, a importância da extensão universitária na problematização e proposição de estratégias de formação, e a transversalidade das temáticas abordadas no projeto com relação às áreas de atuação da terapia ocupacional.

O projeto de extensão pesquisado foi reconhecido, quase que de forma unânime pelos seus participantes, como um espaço que proporcionou aos estudantes o aprimoramento de sua sensibilidade, o protagonismo em seus processos de formação, o reconhecimento do seu papel como agentes de transformação social e a qualificação da atenção produzida nos estágios e campos de atuação profissional. $\mathrm{O}$ fato de se tratar de um projeto de extensão possibilitou, também, que a maior parte dos discentes escolhessem fazer parte dele com base em seus interesses pessoais e em suas demandas de formação profissional, voltados à produção de um cuidado humanizado.

A poesia e demais manifestaçôes artísticas utilizadas nas atividades da extensão proporcionaram aos participantes a valorização de seus saberes e permitiram que se enunciassem de forma potente, inventiva e criadora e inventassem novas formas de se relacionar com o ambiente acadêmico e, para alguns dos participantes, com outros âmbitos da vida.

A composição de poesia, artes e tecnologias leves possibilitaram abertura para o sensível e instauraram um diálogo afetivo entre os sujeitos, o que possibilitou que o projeto fosse significado também como espaço de promoção e produção de saúde, em um contexto acadêmico no qual parecem predominar metodologias tradicionais de ensino e aprendizagem e relações hierarquizadas.

Desta forma, verificou-se que o projeto de extensão possibilitou a criação de contextos de ensino e aprendizagem que promoveram aproximação entre a sensibilidade e afetividade e as práticas educativas e contribuíram para a formação de profissionais que ultrapassem o modelo biomédico, centrado na doença e nas açóes curativas, e desenvolvam açóes que considerem a integralidade das pessoas atendidas, com base na compreensão sensível e contextualizada de seus modos de produção de vida.

\section{Referências}

Andrade, A. D., Vicençotto, A. S., Zaponi, E. P. G., Della Coletta, M., Soragni, M., \& Sartor, N. J. P. (2016). Do sonho à realidade: a arte de viver, conviver e (re)criar. Cadernos Brasileiros de Saúde Mental, 8(20), 195-203.

Antônio, S. (2013). Poetizar o pedagógico: alguns ensaios de modo constelar. São Paulo: Biscalchin.

Brasil. Ministério da Saúde. Núcleo Técnico da Política Nacional de Humanização. (2010). Acolhimento nas práticas de produção de saúde. Brasília. Recuperado em 4 de setembro de 2018, de http://www.bvsms.saude.gov.br

Brasil. (2012, 13 de junho). Resolução no 466, de 12 de dezembro de 2012. Diário Oficial [da] República Federativa do Brasil, Brasília. Recuperado em 28 de abrilo de 2018, de http://www.conselho.saude.gov.br/

Brasil. Ministério da Saúde. Secretaria de Gestão Estratégica e Participativa. Departamento de Apoio à Gestão Participativa. (2013). Politica Nacional de Saúde Integral de Lésbicas, Gays, Bissexuais, Travestis e Transexuais. Brasília. Recuperado em 4 de novembro de 2018, de http://bvsms.saude.gov.br/bvs/publicacoes/politica_nacional_saude_lesbicas_gays.pdf 
Brasil. Ministério do Desenvolvimento Social. (2015). Centro de Referência Especializado de Assistência Social-CREAS. Brasília. Recuperado em 2 de novembro de 2018, de http://mds.gov.br/assuntos/assistencia-social/unidades-de-atendimento/creas

Cancherini, Â., Franco, M. A. S., \& Pontes, R. (2012). A escuta sensível como instrumento metodológico na formação inicial de docentes. Camine: Caminhos da Educação, 4(2), 1-15.

Casate, J. C., \& Corrêa, A. K. (2012). A humanização do cuidado na formação dos profissionais de saúde nos cursos de graduação. Revista da Escola de Enfermagem da USP, 46(1), 219-226. PMid:22441287. http://dx.doi.org/10.1590/S0080-62342012000100029.

Castro, D. E., Inforsato, E. A., Angeli, A. D. A. C. D., \& Lima, E. M. F. A. (2009). Formação em terapia ocupacional na interface das artes e da saúde: a experiência do PACTO. Revista de Terapia Ocupacional da USP, 20(3), 149-154. http://dx.doi.org/10.11606/issn.2238-6149.v20i3p149-156.

Castro, D. E., Inforsato, E. A., Buelau, R. M., Valent, I. U., \& Lima, E. A. (2016). Território e diversidade: trajetórias da terapia ocupacional em experiências de arte e cultura. Cadernos de Terapia Ocupacional da UFSCar, 24(1), 3-12. http://dx.doi.org/10.4322/0104-4931.ctoAO0663.

Coelho, A. E., \& Fonseca, R. M. G. S. (2005). Pensando na relação dialética entre sujeitos sociais. Revista Brasileira de Enfermagem, 58(2), 214-217. PMid:16334191. http://dx.doi.org/10.1590/S003471672005000200017.

Constantinidis, C. T., \& Cunha, C. A. (2013). A formação em terapia ocupacional entre o ideal e o real. Revista de Terapia Ocupacional da USP, 24(2), 149-154. http://dx.doi.org/10.11606/issn.22386149.v24i2p149-154.

eBiografia. (2000a). Cora Coralina: poetisa brasileira. Recuperado em 2 de novembro de 2018, de https://www.ebiografia.com/cora_coralina/

eBiografia. (2000b). Simone de Beauvoir: escritora e filósofa francesa. Recuperado em 2 de novembro de 2018, de https://www.ebiografia.com/simone_de_beauvoir/

Freire, N. R. P. (1967). Educação como prática da liberdade. Rio de Janeiro: Paz e Terra. Recuperado em 4 de novembro de 2018 , de http://www.dhnet.org.br/direitos/militantes/paulofreire/livro_freire_educacao_pratica_liberdade.pdf

Freire, N. R. P. (1987). Educadores de rua uma abordagem crítica: alternativas de atendimento aos meninos de rua. Bogotá: UNICEF. Recuperado em 29 de setembro de 2018, de http://websmed.portoalegre.rs.gov.br/escolas/cmet/material/Paulo-Freire-Educadores-de-Rua.pdf

Furlan, G. P., Campos, I. O., Meneses, K. V. P., Ribeiro, H. M., \& Rodrigues, L. M. M. (2014). Formação profissional de terapeutas ocupacionais e o curso de graduação da Universidade de Brasília. Faculdade de Ceilândia. Cadernos de Terapia Ocupacional da UFSCar, 22(1), 109-119. http://dx.doi.org/10.4322/cto.2014.012.

Gibbs, G. (2009). Análise de dados qualitativos. Porto Alegre: Artmed.

Inforsato, E. A., Castro, E. D., Buelau, R. M., Valent, I. U., Silva, C. M. \& Lima, E. M. F. A. (2017). Arte, corpo, saúde e cultura num território de fazer junto. Fractal: Revista de Psicología, 29(2), 110117.

Itaú Cultural. (2018). Nise da Silveira. São Paulo: Itaú Cultural. Recuperado em 2 de novembro de 2018, de http://enciclopedia.itaucultural.org.br/pessoa3754/nise-da-silveira

Jezine, E. (2004). As práticas curriculares e a extensão universitária. In Anais do $2^{\circ}$ Congresso Brasileiro de Extensão Universitária. Belo Horizonte: UFMG. Recuperado em 28 de agosto de 2018, de https://www.ufmg.br/congrext/Gestao/Gestao12.pdf

Joaquim, R. H. V. T., El-Khatib, U., \& Barba, P. C. S. D. (2016). A integração do processo ensino e aprendizagem de alunas de terapia ocupacional e o cuidado de máes de bebês de risco na hospitalização. Cadernos de Terapia Ocupacional da UFSCar, 24(2), 397-402. http://dx.doi.org/10.4322/0104-4931.ctoRE0729.

Lima, E. M. F. A., Inforsato, E. A., Lima, L. J. C., \& Castro, E. D. (2009). Ação e criação na interface das artes e da saúde. Revista de Terapia Ocupacional da USP, 20(3), 143-148.

http://dx.doi.org/10.11606/issn.2238-6149.v20i3p143-148. 
Mecca, C. R., \& Castro, D. E. (2009). Epifania do acontecer poético: aspectos da experiência estética na relação sujeito-obra em terapia ocupacional. Revista de Terapia Ocupacional da USP, 20(3), 180-187. http://dx.doi.org/10.11606/issn.2238-6149.v20i3p180-187.

Meira, R. M., \& Silva, U. R. (2013). Cultura visual, ensino da arte e cotidiano: hibridismos e paradoxos. Visualidades, 11(2), 37-57.

Mendonça, S. G. L., \& Silva, P. S. (2002). Extensão universitária: uma nova relação com a administração pública. In A. I. Calderón \& H. Sampaio (Eds.), Extensão universitária: ação comunitária em universidades brasileiras (pp. 29-44). São Paulo: Olho d'água.

Merhy, E. E. (2005). O desafio que a educação permanente tem em si: a pedagogia da implicação. Interface - Comunicação, Saúde, Educação, 9(16), 161-177. http://dx.doi.org/10.1590/S141432832005000100015.

Pimentel, A. (2001). O método da análise documental: seu uso numa pesquisa historiográfica. Cadernos de Pesquisas, (114), 179-195. http://dx.doi.org/10.1590/S0100-15742001000300008.

Pope, C., \& Mays, N. (2009). Pesquisa qualitativa na atenção à saúde. Porto Alegre: Artmed.

Sá-Silva, J. R., Almeida, C. D., \& Guindani, J. F. (2009). Pesquisa documental: pistas teóricas e metodológicas. Revista Brasileira de Historia \& Ciências Sociais, 1(1), 1-15.

Siegmann, C. (2006). Pensar e inventar-se: terapia ocupacional como clínica dos afectos (Dissertação de mestrado). Universidade Federal do Rio Grande do Sul, Porto Alegre. Recuperado em 10 de agosto de 2018, de https:/www.lume.ufrgs.br/handle/10183/6578

Villardi, M. L., Cyrino, E. G., \& Berbel, N. A. N. (2015). A problematização em educação em saúde: percepçóes dos professores tutores e alunos. São Paulo: Unesp. Recuperado em 29 de setembro de 2018 , de http://books.scielo.org/id/dgjm7/pdf/villardi-9788579836626.pdf

\section{Contribuiçáo dos Autores}

Vanessa Carolina Santos Francelino foi responsável pela concepçáo do texto, coleta de dados, organizaçáo de fontes e/ou análises e redação do texto. Marília Meyer Bregalda foi responsável pela redação e revisão do texto. Todos os autores aprovaram a versão final do texto.

Autor para correspondência

Vanessa Carolina Santos Francelino

e-mail: vanessafrancelinoto@gmail.com 